\title{
CRACKING THE CITADEL WALLS: A FUNCTIONAL APPROACH TO COSMOPOLITAN PROPERTY MODELS WITHIN AND BEYOND NATIONAL PROPERTY REGIMES
}

\author{
Caterina Sganga
}

\begin{abstract}
Due to its strong connection with sovereignty, territoriality and socio-economic policies, property law is traditionally considered part of the closed citadel of national law. This axiom is reinforced by private international law, where the mandatory principle of lex rei sitae acts as a barrier against the cross-fertilization of national property systems. No international treaty has ever touched the field directly; even in Europe, in spite of the interference of EU acts on national property laws, the Lisbon Treaty leaves property in the exclusive competence of Member States. It is not by accident that the majority of comparative law scholars approach the subject with a state-centric perspective, often emphasising the unbridgeable divide between different property traditions.

Today the citadel is under multilateral attack. Bilateral investment treaties (BITs) and other international agreements break long-lasting dogmas and extend the scope of property to cover not only intangible assets, but also contractual rights and expectations. 'Cosmopolitan' human rights courts use a sui generis comparative approach to develop a similar autonomous conceptualisation of subject matter, structure, and content of property rights, while the potential horizontal effects of their decisions nullify the traditional constitutional/private law property divide. Internet and private ordering push for the cross-border recognition of virtual or quasi-proprietary entitlements, questioning the fundamental separation between property and contract and the sanctity of the numerus clausus principle. No matter how vigorously legal formants have tried to reinforce the citadel walls, these cosmopolitan 'irritants' have already engendered several interpretative short-circuits, which a state-centric comparative analysis is unable to deconstruct and explain. To overcome the impasse, this paper advocates for the adoption of the functional method to verify the existence of a new global property model, sketch out its main characteristics, and help national legal systems embedding these new cosmopolitan elements, whether within or outside property law.
\end{abstract}

\section{Keywords}

Property law, cosmopolitanism, human rights, virtual property

* Assistant Professor of Law, Central European University.

Copyright $\odot$ the Author(s).

This work is licensed under a Creative Commons Attribution-NonCommercial-NoDerivs 3.0 License. 


\section{Introduction}

No other area of private law has been more consistently defended against any historical attempt of supranational standardization or cross-border contamination than the law of property. Roman law knew the distinction between the dominium protected by the ius civile, applied only to Roman citizens, and the ownership (or in bonis habere) protected by the ius gentium. ${ }^{1}$ The feudal system was characterized by highly fragmented, different ownership models, based on local customs, and tightly linked with the correspondent social and political structures. ${ }^{2}$ When nation states emerged in continental Europe and wanted to assert territorial sovereignty, they introduced new, unified national property regimes. ${ }^{3}$ Then, with the development of private international law, the aversion against crossborder contaminations led to the horizontal predominance of the rule of lex rei sitae. ${ }^{4}$ Even recently, after the fall of the Berlin Wall and the dissolution of the Soviet Union, the new republics opted for a huge variety of property regimes, each of them mirroring the country's national and ideological identity. ${ }^{5}$

The main reason underlying the territorial nature of property rights and their traditional non-involvement in lex mercatoria can be historically pinpointed to the fact that, at least until the first half of the $20^{\text {th }}$ century, wealth was mostly embedded in land, the immovable par excellence. However, this objective characteristic soon turned into a wilful localization, differentiation and impenetrability of property regimes by any sort of external influences. The roots of this 'property exceptionalism'6 are manifold and intertwined. Ownership deals with the distribution and management of resources, thus it reflects the structure of economic activities and the ideological stances of local communities. ${ }^{7}$ At the same

1 For an analysis of the differences between these two systems of property law see A Borkowski \& P D U Plessis, Textbook on Roman Law ( ${ }^{\text {rd }}$ edn, 2005) 101, 157.

2 See F Pollock \& F W Maitland, The History of English Law Before the Time of Edward I ( $2^{\text {nd }}$ edn, 1899) 235; T F T Plucknett, A Concise History of the Common Law (5 ${ }^{\text {th }}$ edn, 1956) 506.

3 The clearest example comes from France: see B Terrat, 'Du régime de la propriété dans le Code Civil', in J-L Halperin (ed), Le Code Civil 1804-1904, Livre du centenaire (1904) 329ff. See also K G C Reid, 'Vassals No More: Feudalism; Post-feudalism in Scotland' [2003] European Review of Private Law 282.

4 See H Yntema, 'The Historic Basis of Private International Law' (1953) 2 AJCL 297, 305.

5 As reported by Z Lerman, C Csaki \& G Feder, Agriculture in Transition: Land Policies and Evolving Farm Structures in Post-Soviet Countries (2004) ch 3.

${ }^{6}$ As analyzed in greater detail by D Caruso, 'Private Law and Public Stakes in European Integration: The Case of Property' (2004) 10 European LJ 751, 755ff.

${ }^{7}$ From an economic standpoint see generally S Shavell, Foundations of Economic Analysis of Law (2008) ch 2. 
time, property is equal to control, thus it is closely linked with sovereignty and the construction and regulation of social structures. ${ }^{8}$ As a consequence, any modification in the social, cultural, economic, political and ideological traits of a community is reflected in changes of local property rules, and the reverse is equally true. This explains the turn from common property to enclosures when societies abandoned nomadic hunting in favour of stable agricultural economies. It clarifies why fragmented property interests were fundamental in creating and maintaining social and political order during the feudal era. It justifies the nation states' ban against feudal entitlements, in favour of a unitary concept of ownership and the crystallization of property regimes in rigid dogmas and mandatory rules, in order to reinforce the new centralized exercise of sovereignty. ${ }^{9}$ More recently, these factors shed light on the reasons why property exceptionalism has re-emerged when the globalization of commerce and the advent of human rights treaties have posed the pressing need of transnational legal integration. ${ }^{10}$

The walls protecting the citadel of national property laws are thick and resilient. Some are spelled out in written rules and principles, while some others are hidden products of the centuries-long development of national property regimes. Provisions like the principle of lex rei sitae imposes the respect of the boundaries set by national property rules; ${ }^{11}$ parallel to this, the numerus clausus principle excludes the possibility for party autonomy and for foreign titles to create new proprietary rights outside the catalogue provided by national laws, or to alter the structure and content of existing entitlements. ${ }^{12}$ At the same time, hidden systemic factors make it difficult, or nearly impossible for national legal formants to engage in cross-border exchanges and to facilitate forms of bottom-up convergence. First, local property discourses have been historically influenced by language, concepts and structures of subjects like moral philosophy, economics, political theories, and jurisprudence. ${ }^{13}$ Their different degrees of

\footnotetext{
${ }^{8}$ See the landmark contribution of M R Cohen, 'Property and Sovereignty' (1927) 13 Cornell LQ 8.

9 Similarly, in historical perspective, see U Mattei, Basic Principles of Property Law. A Comparative Legal and Economic Introduction (2000).

${ }^{10}$ As pointed out by Caruso, above $\mathrm{n} 6,755 \mathrm{ff}$.

${ }^{11}$ For an overview on national applications of the principle, see B Akkermans \& E Ramaekers, 'Lex Rei Sitae In Perspective: National Development of a Common Rule?' (Maastricht European Private Law Institute Working Paper No 2012/14, 2012), <http://papers.ssrn.com/sol3/papers.cfm?abstract_id $=2063494>$ [accessed 15 April 2014].

${ }_{12}$ On the issue see B Akkermans, The Numerus Clausus Principle in European Property Law (2008) 19-80.

${ }^{13}$ As very clearly explained by A Gambaro, 'Property Rights in Comparative Perspective: Why Property Is So Ancient and Durable' (2011) 26 Tulane European and Civil Law Forum 205.
} 
impact on national models caused divergent doctrinal outputs and legislative results. ${ }^{14}$ Second, national property regimes are constituted by a dense overlap of multidisciplinary and multilevel sources. Their interplay, which is often unfathomable from the outside, varies according to the institutional dynamics characterizing each legal system, ${ }^{15}$ so much that apparently similar property rules may produce completely different operational results in different countries. In addition, most of these rules are conceived as mandatory in light of the erga omnes effects of real rights. As a consequence, courts approach the subject with a strictly deferential attitude, and are very rarely keen to provide creative interpretations, that would allow the legal system to evolve and internalize external interferences.

It is no wonder that comparative law has showed little or no interest towards the subject until recently. The great divides among legal traditions, the rigidity of property regimes, the huge diversity in terminology and basic structures, and the resistance against changes and circulation of legal models have made property law a much less fertile soil for comparative exercises than the law of contract and tort. ${ }^{16}$ Fortunately, the trend seems to have changed from the beginning of this century, when several interesting contributions started engaging in interdisciplinary comparative studies, or used historical analysis to reveal the common roots of modern property regimes and to explain how their great semantic, conceptual and structural differences have developed and crystallized through the centuries. ${ }^{17}$ And yet, notwithstanding their innovation, most of these studies concentrate on the divide between property models and on the impossibility or non-desirability of their convergence. This focus has thus made them of little to no practical use in understanding and tackling the growing movement towards cross-border standardization of property regimes.

The first sign of this phenomenon came from the progressive interference of EU law on national property models. In response to the several inconsistencies generated by the harmonization process and to the shortcomings of traditional comparative studies in understanding and explaining the phenomenon, European scholars have slowly modified their methodological and conceptual approach to the subject, as shown by the inclusion of property topics in the Draft

${ }^{14}$ Ibid, 215-23. See also S Van Erp, 'Comparative Property Law', in M Reimann \& R Zimmerman (eds) The Oxford Companion to Comparative Law (2008) 1043.

${ }^{15}$ With a focus on land law, see A Lehavi, 'The Global Law of the Land' (2010) 81 U Co LR 425, 430-8.

${ }^{16}$ As emphasized by A Gambaro, 'Preface', in M E Sanchez Jordan \& A Gambaro (eds), Land Law in Comparative Perspective (2002) vii.

${ }^{17}$ For a literature overview, see Van Erp, above n 14, at 1045-7. 
Common Frame of Reference ${ }^{18}$ (DCFR), or by the increasing number of 'common core' contributions in the field. ${ }^{19}$

However, the attacks against the thick walls of the citadel have recently gone far beyond a few mere instances of regional harmonization. Several signs suggest the emergence of a broader, global set of property concepts and principles, arising from the unprecedented growth in the interferences of supranational sources, both public and private, on national property systems. Confronted with the quest to internalize these new concepts in the dense web of national property rules, local legal formants have reacted inconsistently, showing the incapability to adapt old rules to new challenges. For the particular characteristics of national property regimes, these cosmopolitan incidents have in fact acted as Teubnerian legal irritants, ${ }^{20}$ producing unexpected and controversial reactions.

A diachronic comparative analysis of property models may help to grasp the reasons why a legal system developed specific rules to deal with particular factual problems, but does not assist legal formants in discovering those common operational traits that are needed to make legal systems communicate and avoid counterproductive reactions vis-à-vis any attempt of supranational standardization. The main theoretical underpinning of this article is that the adoption of the functional method may help: (a) national legal systems in embedding, instead of merely rejecting or passively absorbing, these new cosmopolitan irritants, whether within or outside property law; and more theoretically, (b) scholars in verifying whether or not we are witnessing a convergence around the main pillars of a new, cosmopolitan property model.

Part II provides a concise and essential overview of what this paper assumes are three effective examples of cosmopolitan property models, two of them stemming from supranational public sources - the European Court of Human Rights (ECtHR or the Strasbourg Court) and international investment treaties/arbitration - and one created by cross-border, a-territorial private ordering, such as virtual property in the cyberspace. The varying focuses and characteristics of these three examples allow the analysis to touch upon several aspects of national property regimes, ranging from subject matters, structure and content of property rights

\footnotetext{
${ }^{18}$ Study Group on a European Civil Code and the Research Group on EC Private Law, Draft Common Frame of Reference, Full Edition (2009) Book VIII (Acquisition and loss of ownership of goods), Book IX (Proprietary security in movable assets), Book X (Trusts).

${ }^{19}$ Other forthcoming contributions focus on security rights in immovable property, transfer of immovable, time-limited interests in land.

${ }^{20}$ The reference goes to G Teubner, 'Legal Irritants: Good Faith in British Law or How Unifying Law Ends Up in New Divergences' (1998) 61 MLR 11.
} 
to some of the ground rules of property law, such as, e.g. the numerus clausus principle and the great separation between property and contract. Part III explains the reasons why the functional method best fits in the study of these global trends, and applies it to sketch out the main traits of the three models. This assists in verifying the eventual existence of a trend towards the creation of a general global property model, and to propose the use of the functional method to help national legal formants approach and internalize it without extreme 'irritations'.

\section{Cosmopolitan irritants and national property models}

\subsection{Cosmopolitan courts and property models: the European Court of Human Rights}

In 1959, the ECtHR was created to oversee the respect of the European Convention of Human Rights (ECHR) in 47 Member States. In light of the fact that individuals have the right to petition the ECtHR regardless of their citizenship (rights cosmopolitanism), that the Convention is an autonomous source of fundamental/human rights doctrines overlapping national or regional ones (constitutional pluralism), and that a 'decentralized sovereign' ${ }^{21}$ enforces rights without pure internal hierarchy among courts, scholars define the ECHR as a cosmopolitan legal order, and the ECtHR as a cosmopolitan court. ${ }^{22}$

The right to property is protected by Article 1 of the First Protocol (P1(1)), which does not substantially depart from the correspondent provisions of several national Constitutions. However, due to the semantic choices, the inconsistencies in the translations and the unclear connection between the parts of the provision, ${ }^{23}$ the Strasbourg Court plays a fundamental role in spelling out the main characteristics of the property model delineated by the Protocol and, most importantly, its relationship with national property regimes and traditions.

Although the ECtHR shows a relatively high deference towards the socioeconomic policies and legislative decisions of Member States, ${ }^{24}$ the property

${ }^{21}$ The definition is of M Smith, 'Rethinking Sovereignty, Rethinking Revolution' (2008) 36 Phil \& Pub Aff 405, 408.

${ }^{22}$ See A Stone Sweet, 'A Cosmopolitan Legal Order: Constitutional Pluralism and Rights Adjudication in Europe' (2012) 1 Global Constitutionalism 53.

${ }^{23}$ For a more detailed analysis see T Allen, Property and the Human Rights Act 1998 (2005) 28-33.

${ }^{24}$ Ibid, 125-30. 
model delineated by the Court is anything but a mere reflection of general principles and ground rules extracted from national property laws. On the contrary, in several occasions the ECtHR has specified its adherence to the autonomous meaning doctrine, and thus the rejection of any formalistic interpretation of the concept of 'possession' or 'property' that would limit their subject matters within the borders set by national laws. Entitlements may be defined proprietary even if they are not classified as such under domestic law. ${ }^{25}$ In fact, the Court has never gone as far as to state the existence of vested rights when none were recognized at a national level, but its independent approach has relevantly broadened the range of subject matters of proprietary interests. ${ }^{26}$ Aside from intangible goods, such as intellectual property, which were already included within the category of constitutional property in a number of national experiences, ${ }^{27}$ the ECtHR extended the term 'possession' to cover business goodwill, ${ }^{28}$ welfare benefits, ${ }^{29}$ debts, ${ }^{30}$ contractual rights over property, ${ }^{31}$ virtual assets such as domain names, ${ }^{32}$ final judgments, or even causes of action which may qualify as asset in light of their likelihood of success in court. ${ }^{33}$ Moreover, in some cases the Court applied the protection of Article P1(1) to factual possessions based on contracts void under

${ }^{25}$ The most relevant precedent is Gasus Dosier-Und Forderechnik GmbH v Netherlands (1995) 20 EHRR 403.

${ }^{26}$ While this approach was already present in the ECHR's jurisprudence before Gasus v Netherlands (e.g. in Marckx v Belgium (1979) 2 EHRR 330; Inze v Austria (1988) 10 EHRR 394), the Court reiterated its validity and specified its content after the introduction of the autonomous meaning doctrine: see Iatridis $v$ Greece (2000) 30 EHRR 97.

${ }^{27}$ The most significant example comes from Germany, where private law property is strictly corporeal, while Article 14 of the Basic Law (Grundgesetz) and constitutional property have a much broader reach. For an overview on characteristics and reasons of the phenomenon see G Alexander, 'Property as a Fundamental Constitutional Right? The German Example' (Cornell Law Faculty Working Papers No 4/2003, 2003) <http://scholarship.law.cornell.edu/clsops_papers/4> [accessed 15 April 2014].

${ }^{28}$ The protection of business goodwill is broad, and allows the granting of compensation in case of withdrawal of a commercial or professional licence, as in Van Marle v Netherlands (1986) 8 EHRR 483. The principle is confirmed by the opposite result reached in Baquel v France [2004] App Nos 71120/01 (3 February 2004).

${ }^{29}$ See Pine Valley Development v Ireland (1992) 14 EHRR 319; Stretch v United Kingdom (2004) 38 EHRR 12 .

${ }^{30}$ See e.g. Stran Greek Refineries $v$ Greece (1995) 19 EHRR 293.

${ }^{31}$ As in Gasus v Netherlands, above n 25.

${ }^{32}$ Albeit only in a decision on the question of inadmissibility: Paeffgen GmbH v Germany [2007] ECtHR App Nos 25379/04, 21688/05, 21722/05, 21770/05 (18 September 2007).

33 The first and most cited precedent is Pressos Compania Naviera SA v Belgium (1996) 21 EHRR 301. For a critical overview of the relevant case law see Allen, above n 23, 50-7. 
national law, ${ }^{34}$ or on ultra vires representations by public authorities. ${ }^{35}$ Although the ECtHR declares that it is following a comparative (?) approach in the definition of the scope of Article P1(1), the category goes far beyond the largest boundaries set by national regimes. In addition, the lack of a common core of constitutional property doctrines that can be used as a broadly accepted standard makes the property model delineated by the Court not only destined to operate as autonomous regime, but to have as a diversified impact on national property systems as diverse their internal institutional dynamics are.

In regards to the conceptualization of content and structure of property entitlements, the ECtHR's case law presents relatively autonomous traits, albeit not as visibly as in the area of the expansion of their objective scope. As to the content, the particular distinction that Article P1(1) operates among the different types of state interferences sketches out a model that is not always in line with the variety of positions traditionally adopted by Member States. In fact, while the second and third sentences of the provision refer to the commonly accepted doctrines of de jure and de facto expropriation and control over the use of property, and the Court's application does not diverge substantially from national practices, ${ }^{36}$ the first sentence points to any interferences against the 'peaceful enjoyment of possession', and has been used as a broad residual claus $^{37}$. The breadth of the rule has allowed the Court to grant protection to holders of limited rights, such as leasehold, ${ }^{38}$ licenses $^{39}$ and other types of contractual rights, but also to censor interventions against a single stick of the bundle of rights constituting ownership, ${ }^{40}$ thus adhering to the theory of 'conceptual severance,' ${ }^{41}$ according to which every right of the bundle is itself property and deserves compensation if taken away. Although the Court classifies

${ }^{34}$ See Beyeler v Italy (2001) 33 EHRR 52; Kotterls \& Schittily v Austria (2003) 37 EHRR CD205.

${ }^{35}$ See e.g. Stretch $v$ United Kingdom (2004) 38 EHRR 12.

${ }^{36}$ Although in the case of the third sentence the ECHR has read the provision in an extensive manner: see e.g. Chassagnou v France (2000) 29 EHRR 615 (on restrictions on the right of possession); Marckx v Belgium (1979) 2 EHRR 330 (on restrictions on the right of disposition).

37 The first decision spelling out the tripartite structure of Article P1(1) is Sporrong \& Lonnroth $v$ Sweden [1986] ECtHR App No 11189/84 (11 December 1986).

${ }^{38}$ See e.g. Iatridis $v$ Greece (2000) 30 EHRR 301.

${ }^{39}$ See above $\mathrm{n} 28$.

${ }^{40}$ Frascino v Italy [2003] ECtHR App No 35227/97 (11 December 2003), where the Court included the jus aedificandi in the bundle of rights constituting ownership, despite of the opposite view of Italy and other Member States, and compensated its impairment.

41 The term is used by M J Radin, 'The Liberal Conception of Property: Cross Currents in the Jurisprudence of Takings' (1988) 88 Columbia LR 1667, 1676, to describe the position taken in R A Epstein, Takings: Private Property and the Power of Eminent Domain (1985) 75. 
as expropriation only the formal or substantial taking of the full bundle, the protection of each 'stick' allows for the creation of an internal hierarchy among proprietary prerogatives. This has obviously a strong impact on how the content of property rights is conceptualized and understood, both within and beyond the borders of constitutional property and its protection vis-à-vis the public power.

On the side of structure, the position adopted by the Court, if compared to the models followed by Member States, is of a hybrid nature, where the impact of the interference is sometimes defined in terms of social function of property or, more often, in terms of economic loss. ${ }^{42}$ Such an approach is particularly visible in the application of the fair balance and proportionality test, where the ECtHR weights the goal of the regulation against the nature of the intervention, and the availability of less invasive, drastic means to achieve the same goal. Here, the analysis focuses mostly on the economic losses suffered by the victim, measured in an objective way. ${ }^{43}$ Although some relevance is given to the type of asset involved, so that commercial property is less protected than an asset or right more connected to individual autonomy and dignity, ${ }^{44}$ the concept of social function typical of several Member States' constitutional traditions does not find its way in Strasbourg. ${ }^{45}$ Once the Court finds that the measure is in pursuant of public interest and that rationality and legality principles are satisfied, the social function concept exhausts its role and leaves the floor to the analysis of the economic impact of the measure. While the concept in itself is not new for the majority of national constitutional property doctrines, the greater emphasis put by the ECtHR on the economic aspects of property may ultimately reduce the balancing test to a calculation exercise, contributes very little to the identification of the 'core' of the right, and does not offer a clear picture on the eventual interplay between private prerogatives and social obligations.

\footnotetext{
${ }^{42}$ So that there is often no violation of Article P1(1) found in absence of economic loss: see e.g. Pitkanen v Finland [2003] ECtHR App No 30507/96 (4 March 2003).

${ }^{43}$ Yet, there are cases where the Court stated that subjective factors might deserve consideration, as in Lallement v France [2002] ECtHR App No 46044/99 (11 April 2002).

${ }^{44}$ The Court specifies it clearly in Gasus v Netherland, above n 25, and in Back v Finland [2004] ECtHR App No 37598/97 (20 July 2004).

${ }^{45}$ See A Riza Coban, Protection of Property Rights Within the European Convention on Human Rights (2004) 72.
} 


\subsection{When property meets international arbitration: BITs and beyond}

What makes international investment law responsible for the creation of a new, cosmopolitan property model detached in its creation and development from national sovereignty is, first of all, its focus. Its main sources are bilateral investment treaties (BITs) stipulated under the ICSID system, joined by a number of other international agreements which pursue the same aim, and are regulated and enforced under a variety of arbitration mechanisms. The goal of BITs, and the reasons underlying the creation and success of this institutional solution, is the reduction of uncertainty for foreign investors about the destiny of their assets and entitlements. ${ }^{46}$ The protection of foreign investments against interferences from the host state finds its closer correspondence in the concept of expropriation, and thus carries with it the use of a specific property discourse. ${ }^{47}$ This model, however, is everything but state-centric. The definitions and ground rules contained in BITs do not necessarily match with those of the laws of the countries involved and, at the same time, a state is usually party to several different BITs, each of them potentially using a different language. ${ }^{48}$ The recourse to arbitration as forum for the resolution of disputes detaches even more significantly the subject from the state, and thus from a localized interpretation and application of property doctrines. ${ }^{49}$ To complete the picture, the 'fair and equitable treatment' principle, which constitutes one of the most common clauses in international investment treaties, has often been interpreted as a provision introducing a sort of lex specialis for aliens, independent from, and if necessary more protective towards investors than, the national standards of the host state. ${ }^{50}$

Such a fragmentation may suggest the impossibility of identifying global trends. ${ }^{51}$ Yet, at least in the field of BITs, the recent practice shows a move

\footnotetext{
${ }^{46}$ As also A Lehavi, 'BITs and Pieces of Property' (2011) 36 Yale JIL 115, 128. For a broader overview see KJ Vandevelde, 'A Brief History of International Investment Agreements' (2005) 12 UC Davis JILP 17.

${ }^{47}$ Similarly, see Lehavi, above n 46, 128.

${ }^{48}$ See the data reported by UNCTAD, Investor-State Dispute Settlement and Impact on Investment Rulemaking (2007) 3-6.

${ }^{49}$ See Y Dezalay \& B G Garth, Dealing in Virtue: International Commercial Arbitration and the Construction of Transnational Legal Order (1996) 31-114.

50 The phenomenon is well described by UNCTAD, above $n$ 48, 50-1.

51 The issue is part of a broader debate on the fragmentation of sources in international law: see e.g. the report of the International Law Commission Study Group, 'Fragmentation of International Law: Difficulties Arising from the Diversification and Expansion of International Law', UN Doc A/CN.4/L.682 (13 April 2006).
} 
towards standardization, with leading capital-exporting states developing their own model treaties, and other states using them as point of reference to follow suit. ${ }^{52}$ Parallel to this, years of arbitral interpretation are slowly leading to the creation of shared principles of international customary law. It is true that, besides BITs, the high number of institutions in charge of enforcing the protection of foreign investments, each belonging to a different regime characterized by specific aims and institutional dynamics, constitutes a serious obstacle to the creation of a common, consistent model. Despite this, the practice shows the existence of a set of shared definitions and principles that may well be considered the core of this new global, investment-oriented property model.

Exactly as in the case of the ECHR and the subsequent ECtHR's case law, the notion of investment provided by international treaties-i.e. the subject matter of their 'proprietary' protection-is much broader than the objective scope of property in most of the legal systems involved, and especially those belonging to the civil law family.

Most BITs use open-ended definitions, covering any asset that is owned or controlled by a foreign investor in the host State, and provide an illustrative list of assets ranging from common movable and immovable property, intellectual property, business concessions, and interests in companies to claims and contractual rights having financial value. ${ }^{53}$ Arbitral tribunals have extended the notion of investments to cover loans, promissory notes, construction contracts, setting up of firms and public concessions agreements, ${ }^{54}$ and have consistently referred to investors' rights as property rights. ${ }^{55}$ Although arbitrators tend to give ample weight to the intention of State parties, a set of cases have developed objective, functional criteria to define more clearly the borders of the category. Fedax $N V$ $v$ Venezuela ${ }^{56}$ and Salini Costruttori SpA and Italstrade SpA $v$ Morocco $^{57}$ describe the basic features of an investment, to be evaluated globally, as duration of the performance, regularity of profit and return, assumption of risk, substantial commitment and significance for the development of the host state. Applying the same functional criteria, other tribunals have limited investors' claims by excluding the

\footnotetext{
52 The trend is recently described by A Newcombe, 'Developments in IAA Treaty Making', in A De Mestral \& C Levesque (eds), Improving International Investment Agreements (2013) 15.

${ }^{53}$ See UNCTAD, above $\mathrm{n} 48$, at 22.

${ }^{54} \mathrm{Ibid}, 66$.

${ }^{55}$ See e.g. Southern Pacific Properties (Middle East) Ltd v Egypt, ICSID Case No ARB/84/3 (Award, 20 May 1992) para 167; Plama Consortium Ltd v Bulgaria, ICSID Case No ARB/03/24 (Decision on Jurisdiction, 8 February 2005) para 128

${ }^{56}$ ICSID Case No ARB/96/3 (Decision on Jurisdiction, 11 July 1998).

${ }^{57}$ ICSID Case No ARB/00/4 (Decision on Jurisdiction, 31 July 2001).
} 
applicability of the notion of investment to, for example, contingent liability like bank guarantees. ${ }^{58}$ All in all, the category covers all the positive assets of a patrimony, if persistent in time and having an economic value, since no formal distinction is made between proprietary and contractual rights. The approach follows the same path traced by the ECtHR, with a possibly looser connection to national property laws and their definitions.

International investment law has also an impact on the traditional dogmatic conceptualizations of content and structure of property rights, through its doctrine of direct and indirect expropriation. Although the many arbitral venues and treaties regulating the issue show a great variety of approaches, it is possible to spot common trends, most of them already belonging to customary international law. ${ }^{59}$ The power of states to enact regulations in the public interest, for example, is generally bound to the respect of the principles of legality and non-discrimination. Governments and private parties may agree on the border between ordinary regulation and indirect expropriation and set specific rules for compensation, while in case of doubt arbitrators must depart from national doctrines and rely only on the intention of the parties and international law standards. ${ }^{60}$ To distinguish indirect expropriation from non-compensable types of regulation, arbitral tribunals have developed a stable set of criteria, where the key element is the impact of the regulatory measure on the investment, that should entail a permanent ${ }^{61}$ and substantial ${ }^{62}$ deprivation of power and control over a formally vested right, as much as to make the asset or investment economically useless. ${ }^{63}$ While a mere reduction of profits is not enough to lament an excessive and compensable interference, the focus on the economic value of the proprietary interest represents a distinctive characteristic of the model ${ }^{64}$ that brings it closer to the US doctrine of regulatory taking than, for example, to the approach of the ECtHR. A similarity with the case law of the Strasbourg Court

\footnotetext{
${ }^{58}$ Joy Mining Machinery Limited v Egypt, ICSID Case No ARB/03/11 (Decision on Jurisdiction, 6 August 2004).

${ }^{59}$ See S R Ratner, 'Regulatory Takings in Institutional Context: Beyond the Fear of Fragmented International Law' (2008) 103 AJIL 475, 490.

${ }^{60}$ For a broader analysis see J Paulsson, Denial of Justice in International Law (2005) $789 \mathrm{ff}$.

${ }^{61} S$ D Myers $v$ Canada, UNCITRAL/NAFTA (Partial Award, 13 November 2000) paras 287-8

${ }^{62}$ Feldman $v$ Mexico, ICSID Case No ARB(AF)/99/1 (Award, 12 December 2002) para 103; Pope $\mathcal{E}^{\circ}$ Talbot $v$ Canada, UNCITRAL/NAFTA (Interim Award, 26 June 2000) para 102.

${ }^{63}$ For more details on the development of the criteria see L Y Fortier \& S L Drymer, 'Indirect Expropriation in the Law of International Investment: I Know It When I See It, or Caveat Investor' (2004) 19 ICSID Rev-FILJ 293, 300-12.

${ }^{64}$ See UNCTAD, above n 48, 59.
} 
can be found, instead, in the emphasis put on the purpose and proportionality of the public benefit with the harm caused to the investor. 65

The vagueness of the factors, coupled with the lack of hierarchy and coordination among tribunals, are undoubtedly conductive to the production of contradictory results, while the different regimes and institutional goals inspiring treaties and correspondent tribunals make it impossible to operate a reductio ad unum of the precedents. However, academic studies comparing decisions adopted in different venues show a much more consistent scenario. ${ }^{66}$ Examples come from the Iran-US Claims Tribunal, that presents a case law coherent with customary international law principles, ${ }^{67}$ and from arbitral tribunals operating under NAFTA Chapter 11, which adhere to a three-prong test that focuses, as usual, on the impact on the investment, the investor's legitimate expectation and the context of the measure. The level of interference should be sufficiently restrictive to substantially deprive the owner of his ability to use, enjoy or dispose of the asset; ${ }^{68}$ parallel to this, the protection extends beyond traditional ownership, up to covering the reliance on specific governmental commitments; ${ }^{69}$ here as well, proportionality, legality, non-discrimination and good faith are the main criteria used in the balance. ${ }^{70}$ Attempts to broaden the definition of indirect expropriation to reach, like in Metalclad $v$ Mexico, ${ }^{71}$ any covert or incidental interference able to impact on the reasonably expected economic benefit of the investment, have been (partially) set aside, ${ }^{72}$ rejected by following awards, ${ }^{73}$ and then severely limited by the trilateral intergovernmental Federal Trade Commission in $2001^{74}$ that required adherence to the minimum standard provided by customary law.

\footnotetext{
${ }^{65}$ The most relevant example is Técnicas Medioambientales Tecmed $v$ Mexico, ICSID Case No ARB(AF)/00/2 (Award, 2003).

${ }^{66}$ See e.g. Ratner, above $\mathrm{n} 59,26 \mathrm{ff}$, who proposes a unifying approach to precedents based on the institutional regimes of which they are products.

${ }^{67}$ For a full review of the most relevant cases see C N Brower \& J D Brueschke, The Iran-United States Claims Tribunal (1998) 369-471.

${ }^{68}$ Pope $\&$ Talbot $v$ Canada, above n 62, paras 102-3.

${ }^{69}$ S D Myers $v$ Canada, above n 61, at 1440.

${ }^{70}$ Fireman's Fund Insurance Co v Mexico, UNCITRAL/NAFTA (Award, 17 July 2006) para 176.

${ }^{71}$ Metalclad Corporation v Mexico, ICSID Case No ARB(AF)/97/1 (Award, 2000).

${ }^{72}$ Mexico v Metalclad Corporation [2001] BCSC 664, paras 77-105 (Canada).

${ }^{73}$ See e.g. Waste Management Inc $v$ United Mexican States, UNCITRAL/NAFTA (Award, 30 April 2004) para 50

${ }^{74}$ NAFTA FTC, Notes of Interpretation of Certain Chapter 11 Provisions (2001) \$B, <http://www.sice.oas.org/tpd/nafta/Commission/CH1lunderstanding_e.asp> [accessed 15 April 2014].
} 
Although it is not as clear as in the ECtHR's case law, here the content of the right is also defined in accordance with the conceptual severance theory, where each stick of the bundle of rights is considered independently, even if expropriation requires the complete nullification of the economic return of the investment. As to the structure, despite the recent push towards the development of a global public interest theory and the introduction of a proportionality test similar to the one used in Strasbourg, ${ }^{75}$ the inspiration of the international investment protection regime reduces per se the emphasis put on the social function of property rights, and justifies a strict economic reading of investments as values demanding specific supranational guarantees and protection. This creates, obviously, a substantial divide between international investment-oriented and many national property models, which is facilitated by the interpretation of international investment protection as lex specialis, thus requiring arbitral tribunals to confer to foreign investors, if necessary, a higher level of protection than the one attributed to nationals of the host state. Albeit inherently discriminatory, this is the reason why the international investment property model can be considered cosmopolitan, and destined to develop and stay.

\subsection{Virtual property: how private ordering may create a new Internet property model}

The creation of property models has been historically reserved to the public power. Today, however, the a-territorial semi-anarchy of the cyberspace is forcing legal formants to face the existence of new entitlements that are generated by private parties according to their needs, often outside the boxes of national dogmatic categories. Their close resemblance to property rights has already created interpretative troubles, and produced controversial output in courtrooms.

The debate over virtual property is seemingly the most eloquent example of what scholars belonging to different legal systems and disciplines defined as the great divide separating the scientific notion of ownership from the layman conceptualization of proprietary interests. ${ }^{76}$ One of the most interesting examples is represented by Internet virtual platforms, where people perform actions that are of fantasy, or mirror real life experiences. In Second Life, for

\footnotetext{
${ }^{75}$ On the global public interest theory see A Kulick, Global Public Interest Theory in International Investment Law (2012) 77-154

${ }^{76}$ Such a divide is one of the key arguments of B Ackemann, Private Property and the Constitution (1977) 23ff. See also J M Moringiello, 'What Virtual Worlds Can Do for Property Law' (2010) 62 Fla LR 159.
} 
example, registered users interact through their online alter-egos (avatars) in a perfectly realistic world. They build up friendly ties and social connections, launch businesses, trade in real estates, buy or build houses, shop for accessories, dresses, and vehicles. To do so, they use an official currency called Linden Dollars, which is sold and exchanged in an official marketplace.

In Bragg $v$ Linden Research, ${ }^{77}$ the plaintiff, a Pennsylvanian lawyer, sued the owner of Second Life for having shut down his avatar and 'confiscated' all the lands, assets and Linden Dollars he owned. In line with Second Life's Terms of Service, Bragg's account was terminated as he took illicit advantage of an exploit in the system to acquire for cheap money some land parcels not yet released by Linden Research. The plaintiff claimed that he held proprietary interests over his Second Life assets, thus he had been victim of a tort of conversion due to Linden's unlawful interference. The defendant rebutted, submitting that the Terms of Service merely license the use of Linden's software and do not create any property right. The case ended up in a settlement, but the arguments raised by the two parties give a clear sense of the nature of the debate and the relevance of the property discourse. Few months later, in Eros LLC v Simon ${ }^{78}$ two successful Second Life traders, engaged in the development and trading of adult-themed items, clothing, furniture and other accessories for avatars, sued another 'entrepreneur', Simon, for having unlawfully copied and sold their materials to other users. They won without great controversy, but on the much plainer and more accepted cause of action of trademark and copyright infringement.

The US rejection against the conceptualization of virtual property entitlements beyond intellectual property rights is only one of the approaches followed worldwide. In China, a number of landmark decisions, both civil and criminal, have recognized and protected the ownership of virtual assets via property law. ${ }^{79}$ Taiwan and South Korea are following the same path through ad hoc legislations, while their courts have been actively protecting online property rights by adapting old rules to the new context. ${ }^{80}$ In 2012, the Dutch Supreme Court (Hoge Raad) defined and sanctioned as theft the illicit subtraction of items used in online videogames, ${ }^{81}$ arguing that the rights over virtual objects may be defined as proprietary since the goods have an objective value depending on the time and

\footnotetext{
77487 F Supp 2d 593 (ED Penn, 2007).

${ }^{78}$ Case No 1:07-cv-04447-SLT-JMA (EDNY, 24 October 2007).

${ }^{79}$ Reported and commented by J Fairfield, 'Virtual Property' (2005) 85 Boston ULR 1047, 1084-5.

${ }^{80}$ Ibid 1087-1089

${ }^{81}$ HR 30 January 2012, ROW 2012/259.
} 
effort invested in gathering them, and they remain under the exclusive control of their owner. The court's reasoning echoed the arguments used for electricity theft, where the intangibility of the good-as well as, here, their quality as data or information-does not play any role in defining the nature of the rights insisting on it.

Similar controversies affect the area of domain names, which are acquiredexactly as access to virtual platforms-through license contracts. The license attributes the exclusive right, limited in time and scope, to use the selected name and to have it associated with a specific IP address. Such conditional contractual right, however, can be freely transferred, has a definite market value, prevents others from using the same name, and can fall into a bankruptcy estate. Although it possesses the functional characteristics that made the Hoge Raad find for the existence of a property right, legal formants tend to assimilate it as much as possible to intellectual property, and to deny any formal recognition-beyond that of contractual rights-if such assimilation proves to be impossible. ${ }^{82}$ In this sense, domain names share the same destiny of other virtual entitlements. Still, the struggle remains when their classification in proprietary terms is relevant-as it often happens-for the production of certain legal effects, such as the possibility for creditors to garnish them. Judicial solutions are anything but consistent. In some instances courts have defined domain names as mere products of a contract for service; ${ }^{83}$ in others, they have found in favour of the applicability of the tort of conversion, since domain names are 'merged in a document' exactly as a debt is in a promissory note. ${ }^{84}$ Similar decisions can be seen in Australia as well. ${ }^{85}$ Meanwhile, in Canada, domain names are considered personal property for the purpose of applying specific jurisdiction rules. ${ }^{86}$ The situation is obviously more complicated in civil law countries, where the category of property rights is entrenched and exclusive rights may be labelled as such only through legislative definition.

Because of their close resemblance to intellectual property rights, domain names have created less classificatory problems than other virtual assets. How-

\footnotetext{
${ }^{82}$ In the US, courts have recognized the property of a domain name only if it was eligible for trademark protection, and a mere contractual right if it was constituted by generic terms: see Dorer $v$ Arel, 60 F Supp 2d 558 (ED Va, 1999); cf more recently, In re Alexandria Surveys Int'l, LLC, 13-CV-00891 (ED Va, 7 November 2013).

${ }^{83}$ Network Solutions Inc $v$ Umbro International Inc et al, 529 SE 2d 80 (2000).

${ }^{84}$ Kremen $v$ Cohen, 337 F 3d 1024 ( $9^{\text {th }}$ Cir, 2003).

${ }^{85}$ Hoath $v$ Connect Internet Services Pty Ltd [2006] NSWSC 158.

${ }^{86}$ As in the recent Mold.ca Inc v Moldservices.ca Inc, Ontario SCJ, CV-13-480391 (30 December 2013).
} 
ever, the definition of their legal nature has also been subject to concerns, and has witnessed the periodical use of contractual arguments against their propertisation. Such a transversal, cross-border and cross-systemic aversion may indicate the incompatibility of virtual property with basic principles shared by the majority of property traditions. In fact, the existence of property entitlements over virtual objects would contradict both the numerus clausus principle and the great dogmatic separation between proprietary and contractual rights. In both civil and common law jurisdictions, legal formants agree on the fact that property rights should be standardized in numbers and content by law. The reasons underlying the choice are different, and range from the pure economic prevention of information and transaction costs to the protection of third parties, since property rights are by definition producing erga omnes (real) effects. ${ }^{87}$ This latter characteristic distinguishes proprietary rights from contractual rights, which produce effects only between parties, and thus need less top-down standardization and may leave more freedom and flexibility for private regulation.

Domain names, Second Life assets, email accounts, and cloud storage spaces are created by private companies and are based on software programs. Users obtain access to these resources on the basis of contracts that usually come in the form of license agreements, preferred by intellectual property owners as they help to avoid the conveyance of possession and the consequences attached by law to a normal sale, such as the principle of exhaustion. Regardless of the aim, licenses usually transfer exclusive rights that in the real world would be considered as proprietary interests. In the virtual world, however, the intangible nature of their subject matters present characteristics that makes it more difficult to draw effective analogies and to swiftly apply rules that are conceptualized for material goods. To help bridge the gap, some scholars have proposed to define the boundaries of virtual property by identifying specific functional features such as rivalry, persistence, and interconnectivity. The rationale inspiring the filtering attributes lies in the fact that, by mirroring the characteristics of real-world objects of ownership, they may help to identify those virtual resources that are apt and should be treated, for the sake of the internal coherence of any property regime, as subject matters of property rights.

This approach has the merit of emphasizing how much virtual property shares the same destiny that other assets and entitlements, such as timeshare

\footnotetext{
${ }^{87}$ For a common law perspective see H Hansmann \& R. Kraakman, 'Property, Contract and Verification: The Numerus Clausus Problem and the Divisibility of Rights' (2002) $31 \mathrm{~J} \mathrm{Leg} \mathrm{Stud}$ S373; T W Merrill \& H E Smith, 'Optimal Standardization in the Law of Property: The Numerus Clausus Principle' (2000) 110 Yale LJ 1.
} 
ownership or dematerialized securities, faced in the last century. It was the adoption of a less dogmatic, more factual-oriented and functional approach to the problem that helped to envisage their proper categorization and eased the communication between legal systems. Today, the same functional approach has led the Court of Justice of the European Union to rule that the principle of exhaustion also applies to software license agreements, in so far that the characteristics of the transaction suggests that the object of the transfer was ownership and not mere use rights. ${ }^{88}$ The same rationale inspires the Uniform Commercial Code, which demands the functional reclassification of leases as secured sales or security interests, ${ }^{89}$ or the definition of a reservation of title in terms of security interest, ${ }^{90}$ if such reclassification is required to better reflect the economic elements of the deal. Although this type of 'reality check' is not common in the field of licenses, some courts have already focused on the payment schedule and the duration of the possessory interests transferred with the contracts in order to re-label them as sales, ${ }^{91}$ thus implicitly accepting the classification of the rights so conveyed in terms of ownership.

The analysis of the entitlements on virtual goods such as avatars, lands and other commodities generated and exchanged over online platforms presents further layers of complications, for they are contingent by-products of a licensed software program. Intellectual property laws and Terms of Service may provide guidance in deciding on the attribution of exclusive rights over users' creations. Yet, the problem of defining users' and providers' rights and obligations over non-IP assets remains. While leaving the solution to private ordering is a feasible policy option, it will still not help in tackling the risk of inconsistent court decisions, and the 'irritation' of national property regimes that may be generated by the cross-border circulation of enforceable judgments.

Although these three models are very different in focus and characteristics, they all share the redefinition at the supranational, cosmopolitan level of the most basic elements of property regimes, such as subject matter, content and structure of property rights, and some of their ground principles and rules. Their 'irritating' impacts on national legal systems have confronted scholars

${ }^{88}$ Case C-128/11, UsedSoft GmbH v Oracle International Corp [2012] OJ C 287/16, 22.9.2012. For a comment see D Van Engelen, 'UsedSoft v Oracle: the ECJ Quietly Reveals a New European Property Right in "Bits \& Bytes"” (2012) 1 European Property LJ 317.

${ }^{89}$ UCC $\$ \$ 1-203(\mathrm{~b})(1)-(4)$.

${ }^{90}$ UCC $\$ 2-401$.

${ }^{91}$ See e.g. In re DAK Industries Inc, 66 F 3d 1091 (9th Cir, 1995); UMG Recordings Inc v Augusto, $558 \mathrm{~F}$ Supp 2d 1055 (CD Cal, 2008). 
with much more conflicting outputs and greater interpretative problems than those engendered by regional harmonization processes. However, not enough attention has been devoted to the approach comparative lawyers should adopt in order to deconstruct, and thus understand the characteristics of these new models, and to help national legal systems deal with them at best. The next pages will attempt to set the foundations of future research along these lines.

\section{Towards a New Global Property Model?}

When Zweigert and Kotz proposed their praesumptio similitudinis as a tool to discover hidden similarities in apparently different legal solutions, ${ }^{92}$ comparative lawyers found the functional method useful to support the harmonization projects and the quest of legal systems to achieve better interactions and mutual understanding. ${ }^{93}$ However, it did not take long for the method to be targeted by several strains of critiques that underlined its extreme positivism, its complete disregard towards the complexity of law, and the way that its pre-set aims influenced its results. ${ }^{94}$ In fact, these limitations emerged strongly in comparative property law. The original version of functionalism could never find its way in the field, for its goals of forcing the finding of similarities are fully incompatible with the great complexity and divergences of property regimes. Yet, it would be unfair to hastily discard its usefulness without trying to understand, beforehand, the reasons underlying its failure.

The decision of which method to adopt and how to implement it strictly depends on the goals of the investigation. In fact, functionalism may be applied in a variety of ways according to the functions it is meant to perform. ${ }^{95}$ For example, epistemological functionalism comes into play when scholars need to analyse legal phenomena while being shielded from the influence of national path dependence. This may happen when the aim is to make legal systems communicate with one another, or to assess the real need for harmonization. To pursue these goals, the method focuses on the practical functions and effects of

\footnotetext{
${ }_{92} \mathrm{~K}$ Zweigert \& H Kotz, An Introduction to Comparative Law (1998) 32-47.

${ }^{93}$ See C Godt, 'The Functional Comparative Method in European Property Law' (2013) 2 European Property LJ 73, 74.

${ }^{94}$ Broadly reported by R Michaels, 'The Functionalist Method of Comparative Law', in Reimann \& Zimmermann, above n 14, 339.

${ }^{95}$ See, inter alia, J Smits, 'Taking Functionalism Seriously: On the Bright Future of a Contested Method' (2011) 18 MJECL 554; see also M Graziadei, 'The Functionalist Heritage', in P Legrand \& R Munday (eds), Comparative Legal Studies: Traditions and Transitions (2003) 100
} 
legal institutions, and searches for functional equivalents across national regimes. By disregarding formalism and dogmatic classifications, the approach helps in overcoming apparent divergences and fosters intercommunication. ${ }^{96}$ However, in order to do so, it purposefully ignores other elements of complexity, and simplifies as much as possible the analytical framework on which it operates.

If the aim is to compare national property regimes, functionalism is indeed of no value. It does not explain the reasons of the great divide among traditions as much as a historical comparison can do, nor does it unveil the hidden systemic factors that hinder legal systems from engaging in cross-border exchanges, such as the overlap of multidisciplinary and multilevel sources or the influence of non-legal subjects on property rules. Due to its lack of sensitiveness towards complexity, the method is not really able to assist legal formants in internalizing contributions coming from other national regimes.

Yet, with all its inner limitations, functionalism may still be one of the most adequate methods to analyse cosmopolitan property law. Scholars have already proposed the use of the method to perform a systematizing function. ${ }^{97}$ The discovery of functional equivalents may lead to the unveiling of common, implied patterns that may be used to construe an analytical supra-system that is detached from formalistic or dogmatic schemes. This fits in well with the aim of investigating the existence of an independent, supranational property model, which does not follow-at least at a first glance-the logic, categories and institutional dynamics of national property regimes. At the same time, the focus of the method on common functions and effects helps to find a communicative path between the new model and national laws, which may overcome the difficulties posed by the complexity of property regimes, the path dependence of local legal formants and the obstacles posed by private international law. The validity of such an approach may be clearly verified when applying the method to the common traits shared by our three cosmopolitan property models.

The first significant characteristic the three models have in common is the nature of the subject matter of proprietary rights, which goes beyond tangibility and includes any positive asset of a patrimony. In fact, the focus and filter lay on the objective economic value of the good, and not on its nature. Each of them includes contractual rights, thus breaking the traditional, national contract-property divide, and stretches up to cover expectations or, similarly,

\footnotetext{
${ }^{96}$ Michaels, above n 94, 364-71.

${ }^{97}$ M Rheinstein, 'Teaching Comparative Law' (1937-1938) 5 U Chi LR 615, followed by Zweigert \& Kotz, above n 92, 44-6.
} 
entitlements over virtual objects that do not perfectly fit in the category of absolute rights.

In addition, the ECtHR and international investment arbitration models share a particular approach to the content of property that leans towards a Hohfeldean, ${ }^{98}$ common law conceptual severance of the entitlement in a bundle of separated rights. Nothing similar emerges so clearly in the virtual property model. Yet, the different types of contracts creating digital objects and prerogatives are implicitly inspired by the idea of fragmented, tailor-made exclusive rights. Fragmentation may be considered one of the minimum common denominators of the three models.

The coexistence of rights and obligations in the structure of property and, consequently, its inherently limited nature is reflected in ECtHR's case law. The concept is not fully embedded in the property model delineated by international investment arbitration, but it is recently emerging behind the use of the proportionality test developed by the Strasbourg Court and the development of a global public interest theory. Due to the contractual nature of the rights, on the side of virtual property none of the entitlements may be defined as a fully-fledged property right, although their internal limitations are private and horizontal, and thus of a different nature than those proposed by the other two models. Again, limited property rights are another minimum common denominator.

The three models also share the aversion towards the traditional divide between property and contract law. They challenge the numerus clausus principle from its roots, and opt for a more pragmatic approach to the transparency needed when rights produce third party effects, balanced with the need for flexibility. More generally, their approach interferes substantially with the private/public divide characterizing national property regimes. And the list may continue.

However, the common cosmopolitan reach and the number of significant shared traits do not tell us whether this convergence is effectively leading towards the creation of a global property model. Something else is required.

To deserve the rank of institution, the legal category should perform specific functions in response to particular needs, or be in pursuance of specific goals. ${ }^{99}$

\footnotetext{
${ }^{98}$ Further: W N Hohfeld, 'Fundamental Legal Conceptions as Applied in Judicial Reasoning' (1917) 26 Yale LJ 710.

${ }^{99}$ The definition is borrowed from the new institutionalism of D North, 'Institutions' (1991) $5 \mathrm{~J}$ Economic Perspectives 97. On its application in comparative law, see A Bakardjieva Engelbrekt, 'Toward an Institutional Approach to Comparative Economic Law', in A Bakardjieva Engelbrekt \& J Nergelius (eds), New Directions in Comparative Law (2009) 213, 234.
} 
To be global, it should do it consistently across its various manifestations. To be new, these functions should be sui generis, or at the very least be partially distinct from those performed by national property rights. The question on whether or not this sum of shared traits meets these requirements, and may thus constitute the model of a new global property regime cannot be properly answered by means of traditional exegetic techniques, but the systematizing role of the functional method may offer some relatively solid analytical tools.

In fact, if observed through the lens of functionalism, the approach the three models have towards the subject matter, content and structure of property rights appears to be inspired by specific goals (institution), which are both global and different-at least partially-from those traditionally pursued at the national level.

The expansion of the subject matter suggests that the property sketched by the three models has moved beyond the mere role of right attributed for the distribution, control and management of resources that characterizes national property regimes. ${ }^{100}$ They have all converged on a right institutionalized to protect investments and reliance, as well as to maintain the status quo. This justifies the extension of its scope to cover, for example, contractual rights, expectations, causes of action, and so forth. Although the ECtHR also includes the protection of human rights finalities of property rights, the common function delineated by the three cosmopolitan models still emerges clearly, and attributes to property tasks that national legal systems have traditionally 'distributed' otherwise. ${ }^{101}$ The same function also inspires the option for conceptual severance and fragmented content, where each stick of the bundle of rights composing property is considered separately. This approach favours flexibility and differentiation, but most relevantly, it allows for the attribution of separate objective values to each stick. The operation is of fundamental relevance for property to maintain its role of guardian of investments in the new economy of intangibles. However, at the same time, it represents a clear departure from the unitary ownership model that is typical of modern national property regimes, which has long performed the post-feudal function of protection of individual freedom. The emphasis on the economic aspects of property, and the functions

\footnotetext{
${ }^{100}$ Above $\mathrm{n} 7$.

${ }^{101}$ The metamorphosis, already visible at a national level, is commented on by $\mathrm{R}$ Libchaber, 'La Recodification du Droit des Biens' in J Carbonnier, J-L Halperin, C Jacques \& F Ewald (eds), Le Code Civil 1804-2004, Livre du bicentenaire (2004) 295, in a proposal for a revision of property law in France. See also K J Vandevelde, 'The New Property of the Nineteenth Century: The Development of the Modern Concept of Property' (1980) 29 Buffalo LR 325, 329.
} 
why property is protected and regulated in the new global model are also at the root of the change in the approach to the structure of the right. They justify the general disregard of the linkage between property and the dignity and autonomy of the individual, and explain the partial or complete dismissal of the concept of social function.

The variations in ground rules and principles are also dependent on the mutated functions of property rights (institution). They are shared among the three models (global), and cause a departure from national regimes (new).

Among all, the abandonment of a clear distinction between property and contract is highly indicative and meaningful. The clear-cut separation ceases to make sense once the dogmatic approach to property is substituted by the much more useful and pragmatic reading of property rules inspired by classical economic models. Contract and property become the two extremes on a spectrum where the variety of hybrid situations is and should be broad in order to accommodate a much larger range of needs. ${ }^{102}$ In this context, the traditional numerus clausus principle also mutates its form, in response to the shift of the focus from the protection of third parties and the preservation of the citadel of national property to the reduction of information and transaction costs that may hamper investments and reliance if too high or too incalculable. The new functional equivalents of the principle can be found in the criteria created by arbitral tribunals to limit the category of investments, or by scholars and courts to circumscribe the range of virtual property assets.

These initial results seem already to be enough to suggest the convergence towards a unitary, global property model characterized by specific functions, which are approached and pursued in a different manner than in national property regimes. Such divergences may explain both the tendency of local legal formants to consider national and cosmopolitan property models as separated and independent, and the extreme reluctance of national courts to accept the existence of privately created property models in cyberspace.

In fact, it is undeniably hard for national property regimes to come to terms with cosmopolitan property notions. They do not only differ in terms of basic principles, ground rules and characteristics, but they also obey completely different institutional dynamics and goals, and are influenced by different factors than those impacting the development of national property laws. This

\footnotetext{
${ }^{102}$ The phenomenon, however, is already visible at a national level: see e.g. S Van Erp, 'Contract and Property: Distinct but not Separated' (2013) 2 European Property LJ 240. Further: C Von Bar \& U Drobnig, The Interaction of Contract Law and Tort and Property Law in Europe: A Comparative Study (2004).
} 
makes it impossible for the two systems to have a spontaneous dialogue, and it automatically leads to short-circuit, interpretative misunderstandings, and contradictory outputs.

The only valid solution to overcome the impasse is to adopt a method which can help to deconstruct both the characteristics of the global model and those of the receiving systems, and to make the two communicate with one another without substantially interfering with the structure and regular operation of the receiver. In this sense, the method of functional equivalents is undoubtedly the most suited for the goal. This applies both in case of direct effects of the global model on national legal systems, as in the case of the ECtHR, and in case of more mediated effects, as in the case of international investment arbitration. At the same time, functionalism may help in understanding and offering adequate protection to new assets such as virtual property in a more timely and effective fashion than in the past. To proceed via functional equivalents limits the effort of the receiving legal system to translate the external right in the local legal language and embed it according to its own categories and rules, thus minimizing its involvement and the 'irritations' of its traditional categories. The process, aside of its practical advantages, may also contribute to a better understanding of the regimes involved, opening new paths for the theoretical development of comparative property law vis-à-vis globalization.

\section{Conclusions}

In the last decades, the thick walls of the citadel of national property laws have been under multilateral attack. Apart from the push towards harmonization engendered by processes of economic integration, several supranational sources and institutions-both private and public-are developing property models that substantially depart from national property regimes, and challenge their basic dogmas. No matter how vigorously legal systems have tried to shield themselves, these cosmopolitan incursions have already created an interpretative short-circuit that a state-centric comparative analysis is unable to deconstruct and explain. On the contrary, the features of the functional method makes it fit best to the characteristics of these global regimes.

The study of three examples of supranational property models (ECtHR, international investment law, and virtual property) has shown the presence of some common evolutionary trends. The application of the functional method helps to confirm the existence of a new global property model and to 
sketch its main characteristics. At the same time, it may assist national legal systems in coming to terms with the phenomenon, and in embedding these new cosmopolitan elements-whether within or outside property law. 